\title{
A high-resolution bedrock map for the Antarctic Peninsula
}

\author{
M. Huss ${ }^{1,2, *}$ and D. Farinotti ${ }^{3}$ \\ ${ }^{1}$ Laboratory of Hydraulics, Hydrology and Glaciology (VAW), ETH Zurich, 8093 Zurich, Switzerland \\ ${ }^{2}$ Department of Geosciences, University of Fribourg, 1700 Fribourg, Switzerland \\ ${ }^{3}$ German Research Centre for Geosciences (GFZ), Telegrafenberg, 14473 Potsdam, Germany \\ *Invited contribution by M. Huss, recipient of the EGU Arne Richter Award for Outstanding Young Scientists 2014.
}

Correspondence to: M. Huss (huss@ vaw.baug.ethz.ch)

Received: 23 January 2014 - Published in The Cryosphere Discuss.: 17 February 2014

Revised: 26 May 2014 - Accepted: 12 June 2014 - Published: 18 July 2014

\begin{abstract}
Assessing and projecting the dynamic response of glaciers on the Antarctic Peninsula to changed atmospheric and oceanic forcing requires high-resolution ice thickness data as an essential geometric constraint for ice flow models. Here, we derive a complete bedrock data set for the Antarctic Peninsula north of $70^{\circ} \mathrm{S}$ on a $100 \mathrm{~m}$ grid. We calculate distributed ice thickness based on surface topography and simple ice dynamic modelling. Our approach is constrained with all available thickness measurements from Operation IceBridge and gridded ice flow speeds for the entire study region. The new data set resolves the rugged subglacial topography in great detail, indicates deeply incised troughs, and shows that $34 \%$ of the ice volume is grounded below sea level. The Antarctic Peninsula has the potential to raise global sea level by $69 \pm 5 \mathrm{~mm}$. In comparison to Bedmap2, covering all Antarctica on a $1 \mathrm{~km}$ grid, a significantly higher mean ice thickness $(+48 \%)$ is found.
\end{abstract}

\section{Introduction}

Glaciers of the Antarctic Peninsula strongly differ from the rest of Antarctica regarding their topographical and climatological characteristics and their sensitivity to climate change. The recent collapse of several ice shelves around the Peninsula and the subsequent speed up and mass loss of glaciers feeding them (Rignot et al., 2004; Scambos et al., 2004; Pritchard and Vaughan, 2007; Glasser et al., 2011; Rott et al., 2011) demonstrated the high vulnerability of the region to climate change. Over the last decades, glacier retreat in the region was considerable (Cook et al., 2005) and the Antarc- tic Peninsula and its surroundings are reported to have contributed by almost $30 \%$ to the cryospheric component of sealevel rise since 1960 (Hock et al., 2009). Strong atmospheric warming trends in recent years (Vaughan et al., 2003; Barrand et al., 2013a) and changed oceanic conditions (Meredith and King, 2005) are likely to be the main triggers of the dynamic glacier mass loss.

Ice shelf disintegration and wide-spread surface lowering in coastal areas as observed on the Antarctic Peninsula are also relevant at larger scales for both the Greenland and the Antarctic ice sheet (Pritchard et al., 2009, 2012). Understanding the related processes is crucial for improved projections. However, ice flow modelling requires accurate bedrock data with a comprehensive coverage. Despite major advances in airborne radio-echo sounding of ice thickness in polar regions, the uncertainty in gridded bedrock data still limits the application of state-of-the-art flow models for detailed process studies. For the Antarctic Peninsula, a large number of ice thickness observations is provided by the repeated surveys of Operation IceBridge (OIB) (e.g. Allen, 2013). Ground-based thickness measurements are scarce and are only available for a few individual glaciers (e.g. Farinotti et al., 2013, 2014).

The glaciers of the Antarctic Peninsula are covered by the first complete bedrock data set for Antarctica (BEDMAP, Lythe and Vaughan, 2001). Le Brocq et al. (2010) enhanced BEDMAP by including additional thickness measurements and refined interpolation techniques. However, the grid spacing of both data sets is only $5 \mathrm{~km}$, which is too coarse for resolving the mountain topography of the Peninsula with its narrow subglacial valleys and a high ice thickness variability. 
With the rapid increase in the coverage of thickness measurements, new initiatives have recently contributed to updated bedrock maps for both Greenland (Bamber et al., 2013), and Antarctica (Fretwell et al., 2013) at $1 \mathrm{~km}$ resolution. For the Peninsula, Bedmap2 is a big step forward. Fretwell et al. (2013) interpolated all available bedrock data supported by synthetic ice thicknesses estimated from a simple relation with surface slope.

Whereas for large-scale ice sheet modelling, the spatial resolution provided by Bedmap 2 might be sufficient, detailed considerations of mass balance, ice flow and grounding-line dynamics necessitate the application of models that are able to cope with the high spatial variability of the governing processes. For such models, a high-resolution bedrock topography is an essential geometric constraint.

Over the last decades, several methods for indirectly inferring ice thickness by combining information contained in surface topography with ice dynamic modelling have been developed and applied. Some studies have focused on thickness distribution of individual glaciers in alpine environments (Budd and Allison, 1975; Oerlemans, 1997; Farinotti et al., 2009; McNabb et al., 2012), and have also been applied at the mountain-range scale (Clarke et al., 2013). Other papers have addressed the bedrock topography of a part of Antarctica (Roberts et al., 2011), or for outlet glaciers of the Greenland ice sheet (Morlighem et al., 2013a, 2014). Huss and Farinotti (2012) have presented a data set of ice thickness distribution for each of the world's roughly 200000 glaciers outside of the two ice sheets. The benefit of including flow speed data into the calculation of ice thickness distribution has been demonstrated in a few papers recently (e.g. Morlighem et al., 2011; McNabb et al., 2012) but has so far not been exploited at the regional scale.

Here, we derive a new high-resolution ice thickness and bedrock data set for all glaciers of the Antarctic Peninsula north of $70^{\circ} \mathrm{S}$. By combining simple ice flow modelling with a large number of direct ice thickness measurements from Operation IceBridge, gridded surface velocities and mass balances, local glacier thickness is calculated from characteristics of the glacier surface. This approach allows us to interand extrapolate the scarce thickness observations relying on physical relationships and thus to achieve a highly resolved bedrock estimate. We present the ice thickness distribution of the Antarctic Peninsula on a $100 \mathrm{~m}$ grid, discuss the implications for potential sea-level rise and compare the data set to Bedmap2 (Fretwell et al., 2013).

\section{Data}

Our approach to derive ice thickness makes use of a variety of data sets including surface topography, glacier outlines, surface mass balance, ice thickness, and surface flow speed measurements. Due to the availability of high-resolution input data the study only addresses the Antarctic Peninsula north of $70^{\circ} \mathrm{S}$ (Fig. 1).

A $100 \mathrm{~m}$ digital elevation model (DEM) for the Antarctic Peninsula $\left(63-70^{\circ} \mathrm{S}\right)$ is provided by Cook et al. (2012) based on the Advanced Spaceborne Thermal Emission and Reflection Radiometer (ASTER). Several ASTER scenes acquired over the last decade were stacked and artifacts were corrected resulting in a consistent, smooth and void-filled terrain model for the entire study region. The accuracy of the DEM quantified by comparison to ICESat data is $\pm 25 \mathrm{~m}$ (Cook et al., 2012).

Based on this high-quality DEM, Cook et al. (2014) derived ice flow catchments for 1606 glacier entities. The catchments delimit dynamically connected regions from the highest point of the basin to the calving front or to the grounding line (Fig. 1). We do not consider floating ice in the present study. Catchment areas range between $0.3 \mathrm{~km}^{2}$ and $7000 \mathrm{~km}^{2}$. By intersecting the basin outlines with a detailed vector data set of rock outcrop boundaries retrieved from the SCAR Antarctic Digital Database Version 6.0 (www.add. scar.org) we obtain an ice mask for each individual glacier.

Lenaerts et al. (2012) provide average surface mass balance for the period 1979-2010 based on simulations with the Regional Atmospheric Climate MOdel (RACMO) on a $27 \mathrm{~km}$ grid. RACMO was driven by ERA-Interim data and validated against in situ mass balance measurements. The Peninsula is identified as the region with highest accumulation rates of the Antarctic continent $\left(>1500 \mathrm{~kg} \mathrm{~m}^{-2} \mathrm{yr}^{-1}\right)$. However, only very few direct mass balance observations (e.g. Turner et al., 2002) are available for validation in the study region (Fig. 1).

Between 2002 and the present numerous flight campaigns from NASA's Operation IceBridge (Allen, 2013) covered the Antarctic Peninsula collecting radar-sounding data at $150 \mathrm{MHz}$ using the Multichannel Coherent Radar Depth Sounder (MCoRDS) (see also Shi et al., 2010). OIB provides direct measurements of local ice thickness for 238 individual glaciers on the Peninsula (15\% of the total number). Almost 500000 individual point observations are available along $8500 \mathrm{~km}$ of continuous tracks (Fig. 1). The OIB data yield ice thickness and bed elevation with a nominal accuracy of $10 \mathrm{~m}$ (Gogineni et al., 2001). Actual data accuracy depends on location, quality of bed reflections and uncertainties in the dielectric properties of the ice. Based on cross-over analysis of OIB flight lines on Russell Glacier, Greenland, Morlighem et al. (2013a) found a standard ice thickness error of $31 \mathrm{~m}$. For the Antarctic Peninsula, similar accuracies were confirmed through cross-validation with terrestrial ground-penetrating radar (GPR) on Starbuck Glacier (Farinotti et al., 2014). A maximal deviation of $45 \mathrm{~m} \mathrm{(12 \%}$ of local ice thickness) was found. In addition to OIB data, this study also makes use of ice thickness measurements for Flask and Starbuck Glacier (Fig. 1) based on airborne and ground-based GPR (Farinotti et al., 2013, 2014). 


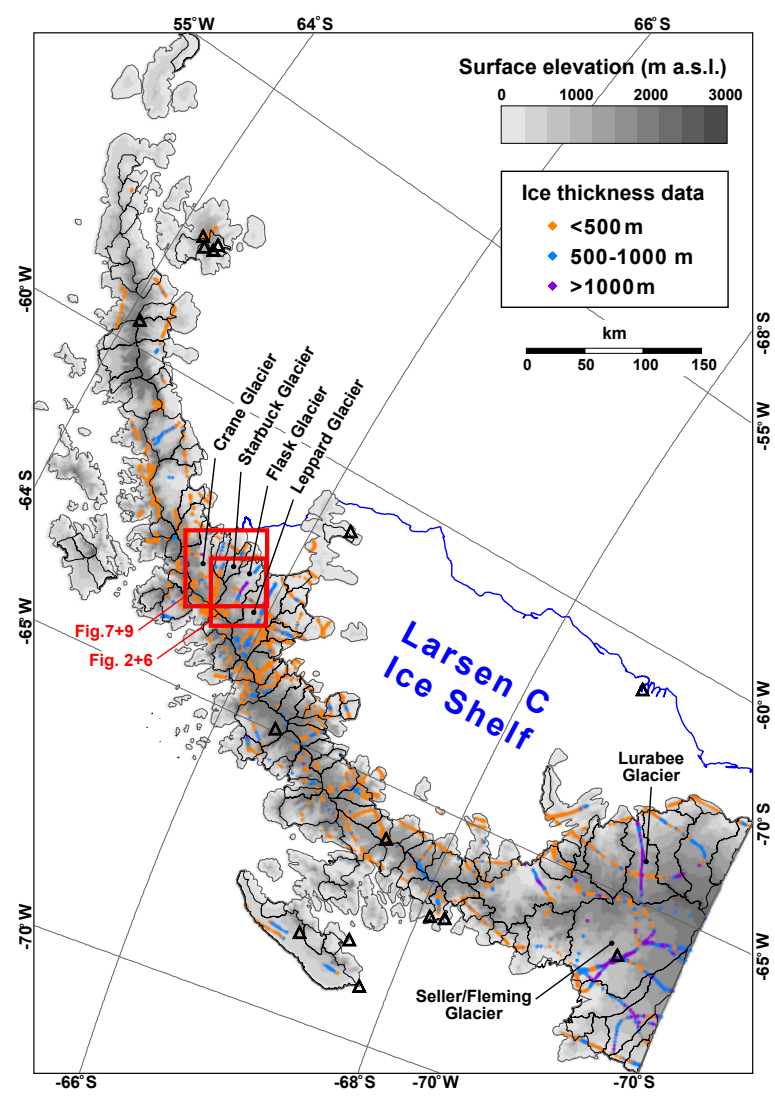

Figure 1. Antarctic Peninsula north of $70^{\circ} \mathrm{S}$. Shading refers to surface topography. Outlines of flow catchments larger than $200 \mathrm{~km}^{2}$ according to Cook et al. (2014) are shown. Ice thickness measurements available from all Operation IceBridge campaigns 20022012 are indicated by dots colour-coded to thickness classes. Triangles show surface mass balance observations (Turner et al., 2002). Ice shelf margins are drawn according to the SCAR Antarctic Digital Database version 6.0. Red rectangles refer to detailed figures.

A comprehensive data set of annual ice flow speed on a $450 \mathrm{~m}$ grid for the entire Antarctic Peninsula is provided by Rignot et al. (2011). Surface velocities have been derived based on satellite radar interferometry using fall 2007 and 2008 imagery from the Advanced Land Observing Satellite (ALOS) PALSAR sensor. The uncertainty in inferred surface speed is estimated at $3-10 \mathrm{~m} \mathrm{yr}^{-1}$ for the Peninsula (Rignot et al., 2011).

\section{Methods}

The basic approach to derive a bedrock data set covering the entire Antarctic Peninsula on a fine grid (100 m resolution) is the constraining of a simple model based on the shallow ice approximation for ice dynamics with a variety of observational data. We invert local ice thickness from surface topography, supported by comprehensive data sets of (i) surface mass balance, (ii) point ice thickness and (iii) ice flow ve- locity. We thus follow recent studies (see e.g. Sellier et al., 2012; Clarke et al., 2013; Morlighem et al., 2013a; van Pelt et al., 2013) that have proposed similar techniques for inferring distributed ice thickness.

\subsection{Modelling approach}

The methodology applied in this study is based on the approach of Huss and Farinotti (2012) which is further developed and adapted to glaciers on the Antarctic Peninsula (see also, Farinotti et al., 2014). Based on surface mass balance, ice volume fluxes along the glacier are determined and are used to compute ice thickness based on Glen's (1955) flow law for ice deformation and assumptions on basal sliding. Contributions of basal mass balance are neglected. As described in Huss and Farinotti (2012), all calculations are performed for a simplified 2-D shape of each individual glacier that is obtained by evaluating glacier characteristics (area, surface slope, length, width) for $10 \mathrm{~m}$ elevation bands of ice surface topography.

Surface mass balance distribution is taken from RACMO (Lenaerts et al., 2012). We perform a spatial downscaling of the RACMO results from their coarse grid $(27 \mathrm{~km})$ to $100 \mathrm{~m}$ resolution by deriving a local, elevation-dependent mass balance function and applying the relation to our fine grid using the DEM of Cook et al. (2012). This function is obtained from linear regression of mass balance vs. surface elevation of the RACMO grid. For every location, the parameters of the regression are estimated through ordinary least-square fits considering a box of $10 \times 10$ RACMO cells. The total surface mass balance is conserved within $<1 \%$ of the original RACMO data set over the study region.

According to mass conservation, ice volume flux along the glacier can be derived by combining information on local surface mass balance $b$ with the elevation change rate $\partial h / \partial t$. From these variables we calculate an apparent mass balance $\widetilde{b}$ (Farinotti et al., 2009) as

$\widetilde{b}=b \cdot f_{\mathrm{RACMO}}-\rho \cdot \frac{\partial h}{\partial t}$,

with $\rho$ the ice density and $f_{\text {RACMO }}$ a dimensionless factor accounting for a potential bias in RACMO mass balances. $f_{\mathrm{RACMO}}$ is treated as a calibration parameter. Whereas glaciers of the Antarctic Peninsula showed moderately negative values of $\partial h / \partial t$ before the year 2000 (Kunz et al., 2012), ice mass loss strongly increased over the last decade for glaciers flowing into the embayment of the former Larsen A and B Ice Shelves (e.g. Berthier et al., 2012). Unfortunately, no complete and distributed data set documenting recent surface elevation changes on the peninsula is yet available. Motivated by results of several studies (Scambos et al., 2004; Pritchard et al., 2009; Berthier et al., 2012; Kunz et al., 2012), we thus roughly parameterize surface elevation changes by prescribing a linear decrease of $\partial h / \partial t$ from $0 \mathrm{~m} \mathrm{yr}^{-1}$ at an elevation of $700 \mathrm{~m}$ a.s.l. to $-10 \mathrm{~m} \mathrm{yr}^{-1}$ at the 

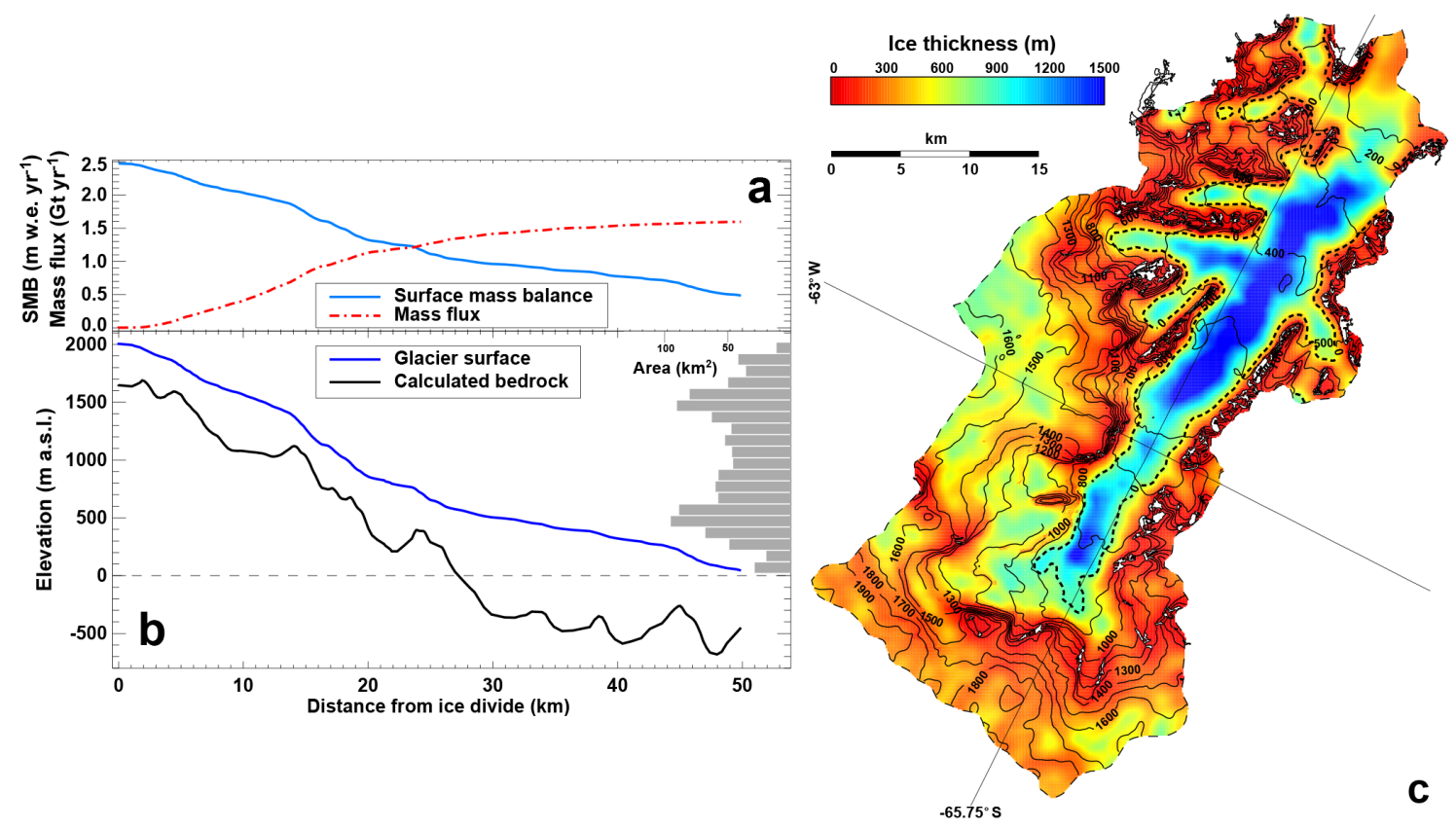

Figure 2. (a) Surface mass balance and mass flux along Flask Glacier (see Fig. 1 for location) according to RACMO (Lenaerts et al., 2012). (b) Surface topography and calculated bedrock (mean of surface elevation bins). The glacier hypsometry is shown by bars. (c) Calculated ice thickness distribution. The spacing of ice surface contours is $100 \mathrm{~m}$. The bedrock elevation corresponding to sea level is indicated by the solid dashed line.

calving front for glaciers flowing into the Larsen A and B embayment, and to $-1 \mathrm{~m} \mathrm{yr}^{-1}$ for all other glaciers. The effect of these poorly constrained assumptions on calculated thickness is assessed with sensitivity tests (see Sect. 4).

By integrating $\widetilde{b}$ from the maximum glacier elevation to the terminus or the grounding line we obtain ice volume flux $q_{\text {tot }}$ for each glacier (Fig. 2a). In the case of an invariant position of the glacier terminus or the grounding line, this also yields frontal ablation (calving, marine melting, flux into ice shelf). By applying an integrated form of the Glen (1955) flow law the ice thickness $h_{i}$ for every elevation band $i$ is calculated (see also Huss and Farinotti, 2012) as

$h_{i}=\sqrt[n+2]{\frac{q_{\mathrm{d}, i}}{2 A_{\mathrm{f}}} \cdot \frac{n+2}{\left(F_{\mathrm{s}, i} \rho g \sin \overline{\alpha_{i}}\right)^{n}}}$,

with $q_{\mathrm{d}, i}$ the deformational component of total ice flux normalized by glacier width $w, n=3$ the exponent of the flow law, $g$ the acceleration of gravity, $\overline{\alpha_{i}}$ the elevation band average of surface slope, and $F_{\mathrm{s}, i}=w_{i} /\left(2 h_{i}+w_{i}\right)$ a valley shape factor (Nye, 1965). As $h$ enters the calculation of $F_{\mathrm{s}}$, Eq. (2) is solved iteratively. The flow rate factor $A_{\mathrm{f}}$ shows a strong dependence on englacial temperatures (e.g. Cuffey and Paterson, 2010), and is used as a second calibration parameter.

The deformational component $q_{\mathrm{d}}$ of the total ice flux $q_{\mathrm{tot}}$ for each elevation band $i$ is computed by prescribing a fraction of basal sliding $f_{\mathrm{sl}}$ relative to surface velocity as

$q_{\mathrm{d}, i}=q_{\mathrm{tot}, i}-q_{\mathrm{b}, i}=q_{\mathrm{tot}, i} \cdot\left(1-\frac{f_{\mathrm{sl}, i}}{(1-r) \cdot f_{\mathrm{sl}, i}+r}\right)$, where $q_{\mathrm{b}}$ is the ice flux due to basal sliding, and $r=(n+$ 1) $/(n+2)=0.8$ is the ratio between average deformational flow speed and surface velocity of an ice column (see e.g. Cuffey and Paterson, 2010).

Parts of Antarctica are known to be warm-based and exhibit significant basal motion (e.g. Kamb, 2001; Joughin et al., 2009). Related to comparably maritime climate conditions, glaciers on the Antarctic Peninsula can be assumed to show considerable basal sliding close to their grounding line but no or limited basal melting and englacial temperatures of -10 to $-15^{\circ} \mathrm{C}$ in their accumulation areas (Zagorodnov et al., 2012). For the Peninsula, Morlighem et al. (2013b) inferred fractions of basal sliding relative to surface flow speed of between about $50 \%$ and $90 \%$ based on modelling. Relying on these findings, we prescribe $f_{\mathrm{sl}}=0.5$ above the median glacier elevation, and parameterize $f_{\mathrm{sl}}$ as a linear function with altitude increasing to $f_{\mathrm{sl}}=0.9$ at the calving front or the grounding line. The impact of these assumptions on calculated thickness and volume is assessed with sensitivity tests (Sect. 4).

Kamb and Echelmeyer (1986) recommend smoothing the basal shear stress $\tau_{i}=F_{\mathrm{s}, i} \rho g \sin \overline{\alpha_{i}}$ over a distance of about 10 times the local ice thickness to account for the influence of longitudinal stress gradients on ice flow. We smooth $\tau$ accordingly and re-introduce it into Eq. (2). Convergence for $h, F_{\mathrm{S}}$ and $\tau$ is reached after about five iterations. The procedure provides mean glacier thickness in $10 \mathrm{~m}$ surface elevation bands along a longitudinal glacier profile (Fig. 2b). 
We then extrapolate calculated mean elevation band thickness from the simplified 2-D shape of the glacier (Fig. 2b) to the $100 \mathrm{~m}$ grid by inversely weighting the distance to the closest rock outcrop, and including surface slope $\alpha$ of each grid cell proportional to $(\sin \alpha)^{-n /(n+2)}$ (based on Eq. 2). Local slopes are filtered with a threshold $\alpha_{\text {cutoff }}=1.5^{\circ}$ because $\sin \alpha$ tends to zero for small values. Furthermore, unrealistic ice thicknesses $h$ larger than $h_{\max }=\frac{z}{\left(\rho_{\mathrm{w}}-\rho\right) / \rho_{\mathrm{w}}}$, with $z$ the surface elevation according to the DEM and $\rho_{\mathrm{w}}$ the density of sea water, are corrected to $h_{\max }$. We thus assume the entire glacier to be grounded within the catchment boundary. This correction affects $1.8 \%$ of the total area. Gridded ice thickness is finally smoothed to remove local noise due to surface roughness. The extrapolation procedure results in a fully distributed estimate of ice thickness for each individual glacier catchment (see Fig. 2c for an example).

\subsection{Model calibration and validation}

To validate model results against observed surface flow velocities we solve Eq. (2) for $q_{\mathrm{d}}$ and take the derivative. This yields average flow speed $u_{i}$ for each glacier elevation band $i$ as

$u_{i}=\frac{2 A_{\mathrm{f}}}{n+1} \cdot\left(F_{\mathrm{s}, i} \rho g \sin \overline{\alpha_{i}}\right)^{n} h_{i}^{n+1}+u_{\mathrm{b}, i}$,

with $u_{\mathrm{b}, i}$ the basal velocity obtained from the prescribed fraction of basal sliding $f_{\mathrm{sl}, i}$. Annual surface motion of each grid cell is then approximated by redistributing $u_{i}$ based on local thickness and slope proportionally to $(\rho g \sin \alpha)^{n} h^{n+1}$ (based on Eq. 4).

The parameters $f_{\mathrm{RACMO}}$ (Eq. 1) and $A_{\mathrm{f}}$ (Eq. 2) are calibrated to optimally match all point observations of OIB ice thickness available for the Antarctic Peninsula, and distributed surface flow velocity. Both parameters are poorly constrained a priori and are thus suitable to tune the model. Whereas lowering $f_{\text {RACMO }}$ results in reduced mass turnover and smaller ice thickness, lower values for $A_{\mathrm{f}}$ lead to stiffer ice and increase calculated thickness. Hence, similar results regarding mean thickness could be achieved with various combinations of the two parameters. It is therefore essential to utilize two independent sets of measured data to determine physically meaningful values for $f_{\mathrm{RACMO}}$ and $A_{\mathrm{f}}$ which are assumed to be constant for the whole domain in our case.

We vary $f_{\mathrm{RACMO}}$ in the range $[0.1,1.0]$, and $A_{\mathrm{f}}$ within $[0.005,0.075] \mathrm{bar}^{-3} \mathrm{yr}^{-1}$ and calculate ice thickness distribution for each of the 1606 glacier catchments of the Antarctic Peninsula with 285 combinations of the two parameters. Measured and calculated point OIB thicknesses are then compared and the mean misfit over all data is evaluated. Calculated surface velocity is resampled to the $450 \mathrm{~m}$ grid of the observations and a point-to-point comparison is performed for catchments $>25 \mathrm{~km}^{2}$ and ice surface elevations $>100 \mathrm{~m}$ a.s.l. We do not integrate small glaciers into this evaluation due to possible uncertainties in measured flow speeds, and exclude areas close to sea level as the shallow ice approximation is not suitable to reproduce flow speeds in the vicinity of the grounding line.

Average misfits close to zero are found for several parameter combinations when considering OIB thickness data or measured ice flow speeds alone (Fig. 3). For the two observational variables, error fields in the parameter space are however almost perpendicular to each other resulting in a unique optimal combination of $f_{\mathrm{RACMO}}=0.71$ and $A_{\mathrm{f}}=$ $0.025 \mathrm{bar}^{-3} \mathrm{yr}^{-1}$. This combination matches the average ice thickness for all OIB data points as well as the spatially distributed flow velocity (Fig. 3).

The plausibility of the inferred values of $f_{\text {RACMO }}$ and $A_{\mathrm{f}}$ is verified by considering independent data sets. Depoorter et al. (2013) estimate annual mass losses in the Larsen $\mathrm{C}$ embayment due to calving and marine melting of about $43 \mathrm{Gt} \mathrm{yr}^{-1}$ (average over 2003-2009). By summing up frontal mass fluxes of all contributing glaciers and including RACMO-based accumulation on the shelf (corrected with $f_{\mathrm{RACMO}}$ ) we find a total flux of $57 \mathrm{Gt} \mathrm{yr}^{-1}$, overcompensating estimated ablation by about one third. Without correcting the RACMO mass balance field $\left(f_{\mathrm{RACMO}}=1.0\right)$ accumulation in the Larsen $C$ embayment would be much higher $\left(79 \mathrm{Gt} \mathrm{yr}^{-1}\right)$, which would result in a strongly positive mass budget when combined with the mass loss data by Depoorter et al. (2013). A tendency towards a positive bias of RACMO for the Antarctic Peninsula is also indicated by comparison to the sparse in situ accumulation observations (see compilation in Turner et al., 2002). Due to inconsistencies at the temporal and spatial scale a direct comparison is however difficult.

According to Cuffey and Paterson (2010), our calibrated value for $A_{\mathrm{f}}$ corresponds to the viscosity of ice at temperatures of between -5 to $-10^{\circ} \mathrm{C}$, which is conceivable compared to the direct measurements by Zagorodnov et al. (2012). These rather rough considerations do not prove the validity of the calibrated parameter values but indicate that they are in a reasonable range, and that our assumptions on basal sliding ( $f_{\mathrm{sl}}$, see Morlighem et al., 2013b) are appropriate.

We compare the average of point-to-point differences of measured and calculated ice thicknesses and surface flow speeds for each glacier individually to observations (Fig. 4). Although this is not a real validation as the bulk data have been used for constraining the model parameters (Fig. 3), valuable information on the performance of our approach at the spatially distributed scale is provided. The average of point thicknesses for individual glaciers is predicted with a mean relative error of $19 \%$ and a root-mean-square error (RMSE) of $102 \mathrm{~m}$ (Fig. 4a). The agreement of calculated glacier-specific flow speed with observations is relatively poor (mean relative error of $50 \%$ ). However, if averaged over glacier size classes, mean surface velocities are well captured (Fig. 4b). This indicates that our approach reproduces the general flow field but shows a lesser performance at the local scale. 


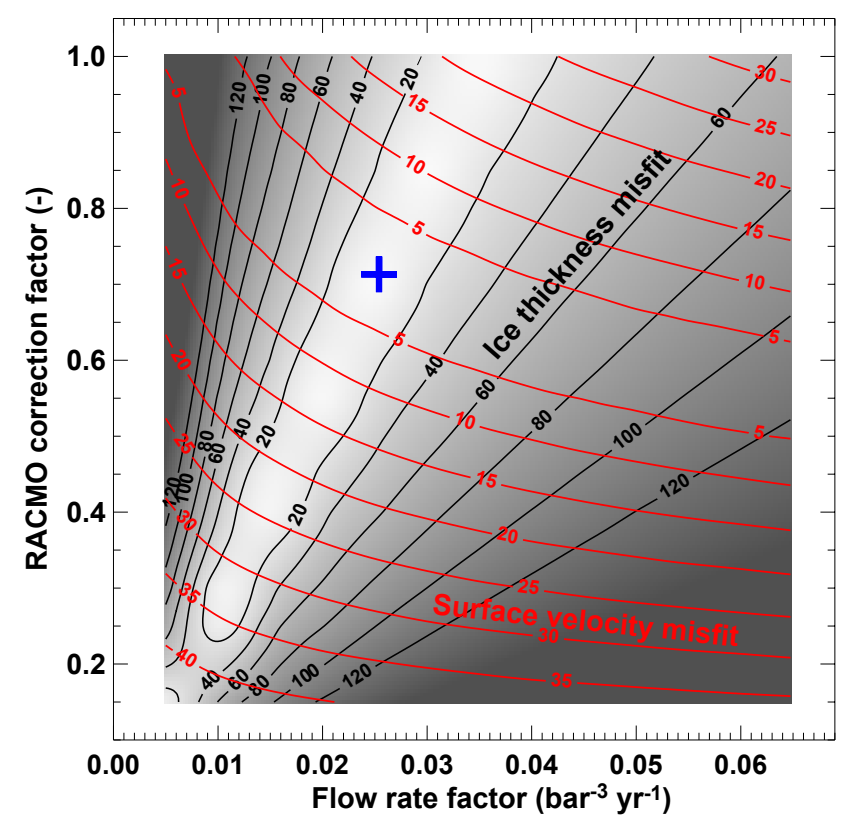

Figure 3. Averaged absolute misfit with OIB thickness data in $\mathrm{m}$ (black contours and grey shading) and ice flow velocity in $\mathrm{m} \mathrm{yr}^{-1}$ (red contours) for different combinations of $f_{\mathrm{RACMO}}$ and $A_{\mathrm{f}}$ (see Eqs. 1 and 2). The optimal parameter combination is indicated by the blue cross.

Observed and simulated thickness is also compared locally. The RMSE over all OIB point measurements is $255 \mathrm{~m}$. There is a tendency of the model to overestimate measured thicknesses of $<500 \mathrm{~m}$ and to underestimate it at locations with $>1000 \mathrm{~m}$ of ice (Fig. 5). The relative errors decrease with ice thickness.

\subsection{Incorporating Operation IceBridge data}

OIB thickness data represent the best and most direct information on bedrock elevation. Despite the generally good agreement of measured and modelled point thicknesses at the glacier-specific scale (Fig. 4a), the model results may deviate by several $100 \mathrm{~m}$ from observations for certain OIB flight lines (Figs. 5 and 6a). We thus incorporate the local OIB data into the ice thickness distribution given by the calibrated model (Fig. 2c). Following Farinotti et al. (2014) the point-based misfit is spatially interpolated for each glacier with OIB data using an inverse distance averaging scheme that results in a 2-D correction field (Fig. 6b). This spatial correction map is then superimposed on the initially modelled thickness distribution. Although this final adjustment can only be performed for $15 \%$ of the glaciers, the coverage in terms of catchment area is high $(71 \%)$ as OIB data are available for most of the large glaciers.
As a final step, the corrected ice thickness distributions of all individual glaciers are combined into a single highresolution grid. As the glacier-specific calculations are independent from each other, results do not necessarily agree at ice divides. We therefore apply a moving window that averages ice thickness smoothly for $1 \mathrm{~km}$ wide bands along the ice divides and corrects local thickness differences. The bedrock topography is then obtained by subtracting calculated thickness from the surface DEM. Gridded ice thickness and bedrock are available at $100 \mathrm{~m}$ resolution from the Supplementary Online Material (SOM).

\section{Uncertainty analysis}

The uncertainty in inferred ice thickness distribution and bedrock topography is composed of several elements. These are separately assessed and combined in order to provide an estimate of (1) the overall uncertainty in ice volume and sealevel equivalent, and (2) the local uncertainty.

The two calibration parameters were determined as the optimal combination to match OIB thickness and surface flow velocity data (Fig. 3). To investigate the robustness of the parameter set to reduced data availability and its validity for different sub-regions of the Peninsula, we divided the study area into four sectors separated by the main topographical divide into a western/eastern part, and the circle of $66^{\circ} \mathrm{S}$ latitude into a northern/southern part. We then re-calibrated $f_{\text {RACMO }}$ and $A_{\mathrm{f}}$ only using thickness and velocity data from one of the four sectors (NW, NE, SW, SE) with the same approach as described in Sects. 3.2 and 3.3. The so determined parameters are optimal for the respective sector but their performance is inferior when applied to the entire study area. By re-calculating the complete bedrock topography with the sectorally calibrated parameters we obtained a range of the overall ice volume due to parameter estimation uncertainty and the spatial representativeness of the data used for calibration. Based on the same procedure, we also included an estimation uncertainty for (i) basal sliding by varying $f_{\mathrm{sl}, i}$ (Eq. 3) by $\pm 20 \%$, and (ii) increasing/decreasing $\partial h / \partial t$ (Eq. 1) by a factor of 2 .

The results of these experiments indicate an uncertainty in calculated total ice volume of $\pm 9.7 \%$. Parameter combinations obtained by calibration solely on the northern (southern) sectors indicate slightly smaller (bigger) thicknesses. The sensitivity of overall ice volume on the assumptions on basal sliding is relatively small $( \pm 1.2 \%)$, and the dependence on the tested range of $\partial h / \partial t$ is minor $( \pm 0.3 \%)$. The modest impact of assumptions on basal sliding on total volume is attributed to the fact that changes in $f_{\mathrm{sl}}$ are partly compensated by the re-calibrated flow rate factor $A_{\mathrm{f}}$.

For estimating the local uncertainty in calculated ice thickness two approaches are combined. (i) We statistically evaluate the skill of the reference result to reproduce point OIB data based on the optimal parameters. Uncertainty $( \pm 1$ 

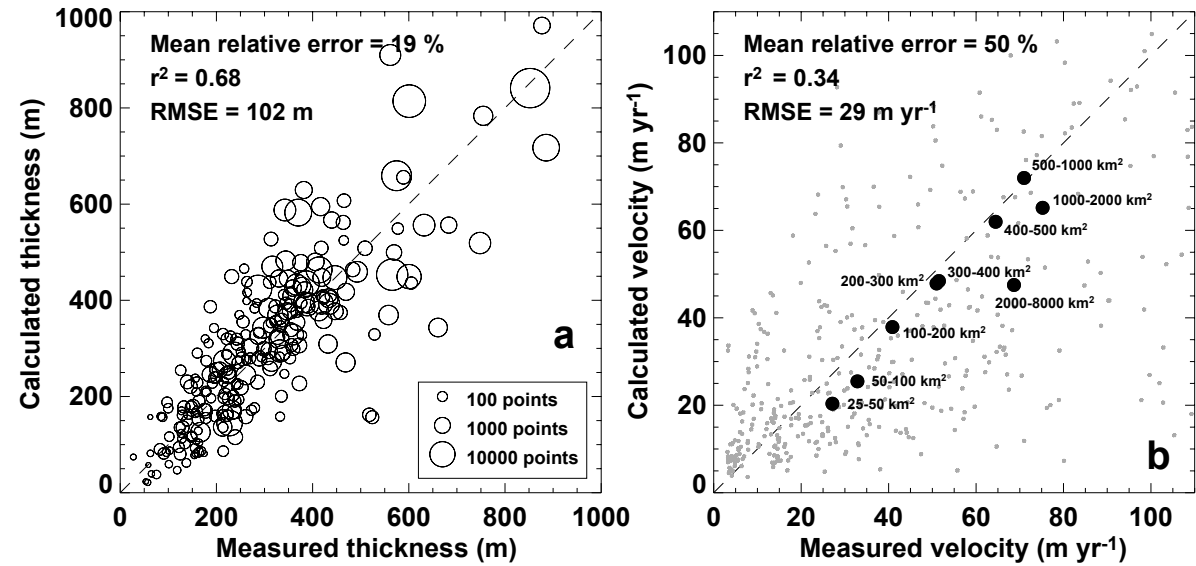

Figure 4. Validation of calculated glacier-specific (a) mean ice thickness (average over all OIB data points) and (b) mean surface flow velocity against measurements. The mean relative error, the correlation coefficient $r^{2}$ and the root-mean-square error (RMSE) are given. The size of the symbols in (a) is proportional to the number of measurements within the glacier catchment. Solid dots in (b) indicate average flow speeds for glacier size classes.

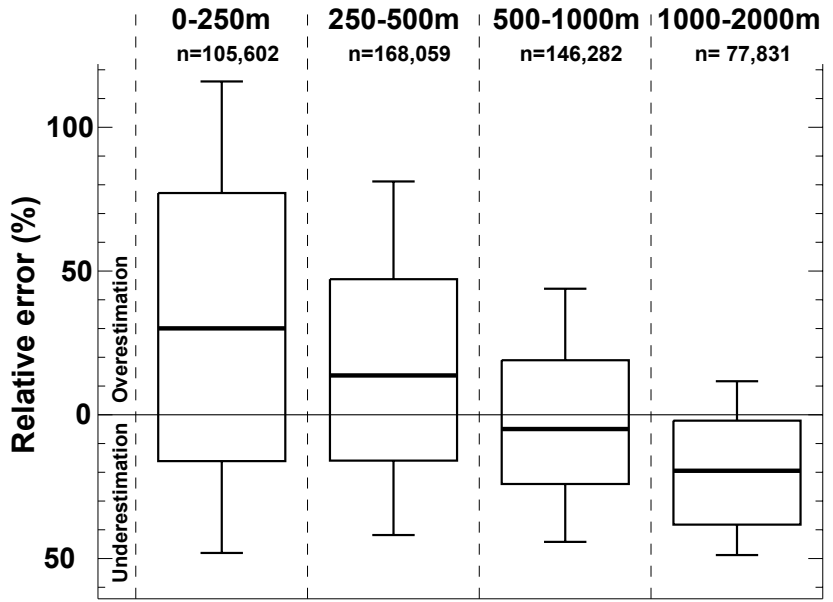

Figure 5. Relative model error for classes of $n$ OIB ice thickness measurements. The solid line shows the median, the box includes $50 \%$ of the data points, and the bars indicate the range between the $10 \%$ and the $90 \%$ quantile.

standard deviation $\sigma$ ) is calculated for $100 \mathrm{~m}$ classes of modelled thickness. $\sigma$ is between 46 and $41 \%$ of local thickness providing a first order uncertainty estimate at an arbitrary unmeasured location. (ii) As we include direct information from OIB data into our final result, the thickness accuracy will be higher in the vicinity of OIB flight lines. Farinotti et al. (2014) accounted for this fact by constructing a distance-dependent uncertainty function, derived from resampling experiments of GPR data from Starbuck Glacier. Here, we adopt this function in normalized form, assuming it to be representative for the entire study region.

Whereas approach (i) yields an uncertainty relative to local ice thickness, approach (ii) provides a correction function for this estimate with values in the range $[0,1]$ being small close to OIB measurement locations and maximal at distances of $15 \mathrm{~km}$ or more from the next thickness sounding. By multiplying the uncertainty grids from the approaches (i) and (ii), an error map for the entire study region is created, providing information on local ice thickness and bedrock uncertainty in both absolute and relative terms (Fig. 7, see SOM for uncertainty map of the entire Antarctic Peninsula). On average, the local thickness uncertainty is $\pm 95 \mathrm{~m}$ but values for deep troughs with no nearby OIB measurements can reach $\pm 500 \mathrm{~m}$. Fortunately, some direct data are available for many large glaciers considerably reducing the total uncertainty (Fig. 7).

\section{Results and discussion}

Our high-resolution bedrock for the Antarctic Peninsula reveals complex subglacial structures with deeply incised troughs and a high ice thickness variability at short spatial scales (Fig. 8). Despite the steep mountain relief a considerable fraction of the ice is grounded below sea level: $23300 \mathrm{~km}^{2}$ ( $24 \%$ of the total) in terms of surface area, and $12000 \pm 2600 \mathrm{~km}^{3}(34 \%)$ in terms of ice volume (Table 1). According to our data set, the mean ice thickness of the Antarctic Peninsula north of $70^{\circ} \mathrm{S}$ is $364 \pm 35 \mathrm{~m}$. For some outlet glaciers, thicknesses of more than $1500 \mathrm{~m}$ are found (e.g. Crane, Flask, Lurabee, Fig. 1) and the bedrock is partly located up to $1000 \mathrm{~m}$ below sea level. This is also supported by OIB data (see Fig. 6a). The total ice volume in the study area is $35100 \pm 3400 \mathrm{~km}^{3}$ (Table 1).

To evaluate the potential sea-level rise contribution of the Antarctic Peninsula we use an ocean surface area of $3.62 \times 10^{8} \mathrm{~km}^{2}$. Average glacier density for every grid cell is obtained by combining calculated ice thickness with results 


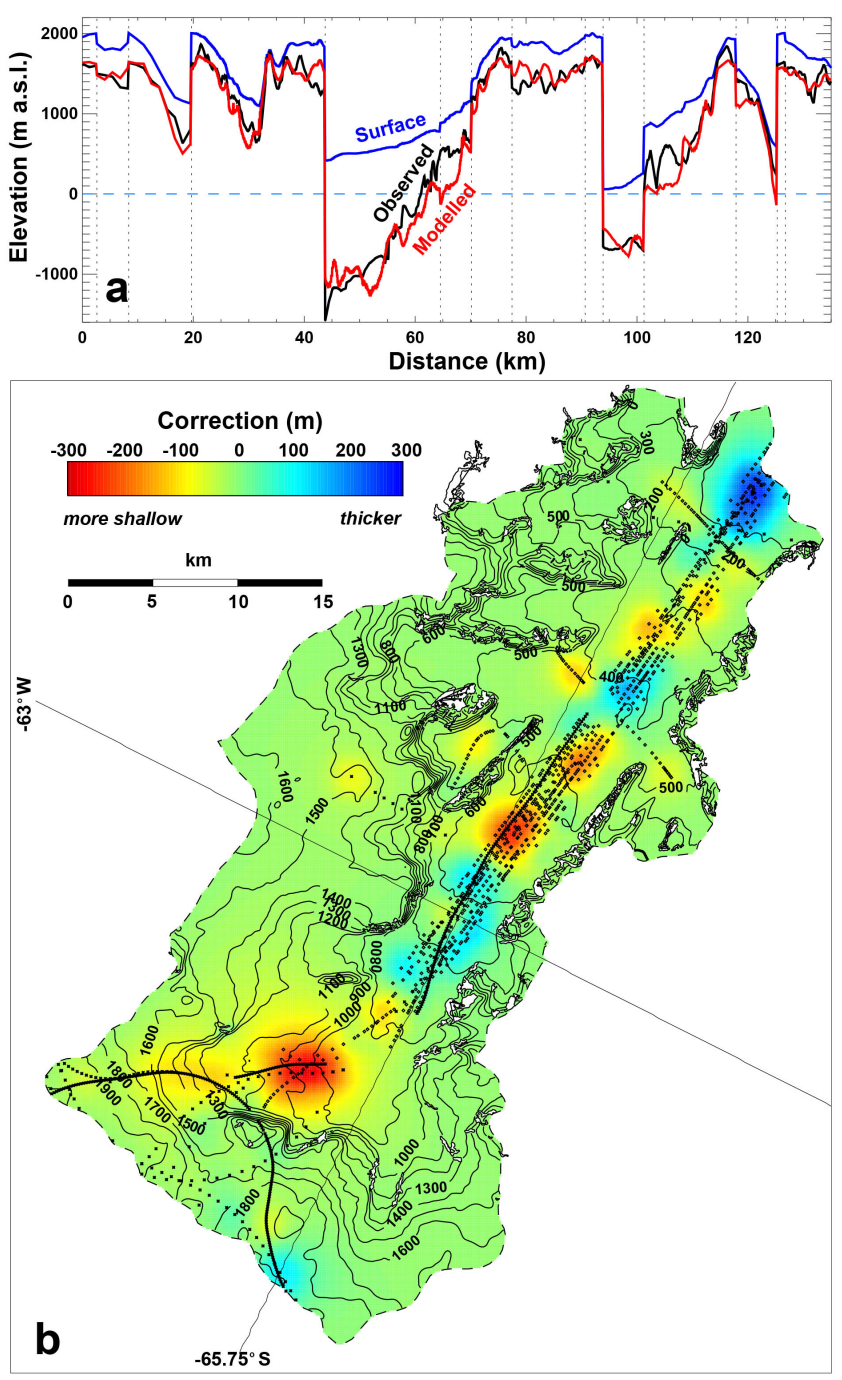

Figure 6. (a) Observed and calculated bedrock elevation of Flask Glacier (Fig. 1) along several OIB flight lines (separated with vertical dotted lines). (b) Interpolated thickness correction field obtained by comparing local ice thickness measurements (black dots) to calculated thickness.

Table 1. Number of glacier basins $n$, surface area $A$, calculated total ice volume $V$, volume grounded below sea level $V_{<0}$, and sea-level equivalent (SLE) for the entire Antarctic Peninsula and sub-regions west/east of the main topographic divide, and north/south of $66^{\circ} \mathrm{S}$.

\begin{tabular}{lrrrrr}
\hline Reg. & $n$ & $\begin{array}{r}A \\
\left(\mathrm{~km}^{2}\right)\end{array}$ & $\begin{array}{r}V \\
\left(10^{3} \mathrm{~km}^{3}\right)\end{array}$ & $\begin{array}{r}V_{<0} \\
\left(10^{3} \mathrm{~km}^{3}\right)\end{array}$ & $\begin{array}{r}\text { SLE } \\
(\mathrm{mm})\end{array}$ \\
\hline NW & 707 & 16389 & $3.9 \pm 0.5$ & $1.1 \pm 0.4$ & $7.8 \pm 0.8$ \\
NE & 248 & 19024 & $6.2 \pm 0.8$ & $3.0 \pm 0.6$ & $10.6 \pm 1.0$ \\
SW & 387 & 31883 & $13.8 \pm 1.2$ & $5.0 \pm 0.5$ & $28.0 \pm 2.1$ \\
SE & 264 & 29131 & $11.2 \pm 0.9$ & $2.9 \pm 1.1$ & $22.4 \pm 1.3$ \\
\hline Tot. & 1606 & 96428 & $35.1 \pm 3.4$ & $12.0 \pm 2.6$ & $68.8 \pm 5.2$ \\
\hline
\end{tabular}

of a firn densification model (Ligtenberg et al., 2011) driven by RACMO at $5.5 \mathrm{~km}$ resolution (see Ligtenberg, 2014, for a description). Over the glacier volume analysed, a mean density of $852 \mathrm{~kg} \mathrm{~m}^{-3}$ is found. For ice grounded above sea level we calculate the contributing ice mass by using local glacier densities. For ice grounded below sea level only the mass between the ice-equivalent surface and the elevation corresponding to flotation level effectively contributes to sea-level rise (see also Fretwell et al., 2013). Floating ice has a small positive effect on sea level due to dilution of ocean waters (Jenkins and Holland, 2007) which is however not accounted for here.

The Antarctic Peninsula north of $70^{\circ} \mathrm{S}$ has the potential to raise global sea level by $0.069 \pm 0.005 \mathrm{~m}$, which is negligible compared to the entire Antarctic ice sheet $(58 \mathrm{~m}$, Fretwell et al., 2013). However, considering the short response time of glaciers on the Peninsula (e.g. Barrand et al., 2013b), it needs to be taken into account in decadal-scale projections. Compared to other glacierized mountain ranges around the globe, the contribution potential of the Antarctic Peninsula is on a par with Arctic Canada and is significantly higher than that from e.g. Alaska, the Russian Arctic, Patagonia or High Mountain Asia (Huss and Farinotti, 2012).

The regional distribution of glacier area and volume is compiled in Table 1. North of $66^{\circ} \mathrm{S}$ (sectors NW and NE) the Peninsula is characterized by a large number of glaciers, smaller average thicknesses and a sea-level rise contribution potential of $27 \%$ relative to the whole study area. The largest average ice thickness is found in the southwest dominated by wide and flat glaciers (Seller/Fleming) that are based below sea level over much of their area. Glacier catchments in the southeast have the largest average size and are still buttressed by the Larsen C Ice Shelf. They exhibit slightly less volume related to higher average surface slopes.

In comparison to Bedmap2 (Fretwell et al., 2013), our new bedrock for the Antarctic Peninsula provides a ten times higher resolution and significantly more details on the subsurface topography. We capture many features of small-scale variability that were lost in the $1 \mathrm{~km}$ grid of Bedmap2 such as narrow subglacial troughs or smaller ice thicknesses around rock outcrops.

Fretwell et al. (2013) state a total sea-level rise potential of $0.2 \mathrm{~m}$ for the Peninsula, which is substantially more than our estimate. Their evaluation is however based on a much larger area and is not directly comparable. We compared the new high-resolution bedrock data set to Bedmap2 for the study region by resampling our thicknesses to a $1 \mathrm{~km}$ grid and cropping it with the rock mask of Bedmap2. According to our data set, mean ice thickness is $124 \mathrm{~m}(+48 \%)$ higher than for Bedmap2. Hence, the difference is beyond the error bounds of the present assessment. The larger ice thickness might be explained with extrapolation from the sparse and non-representative ice thickness observations into unmeasured regions in the creation of Bedmap2, and with the smoothing introduced by the too-coarse grid resolution. 

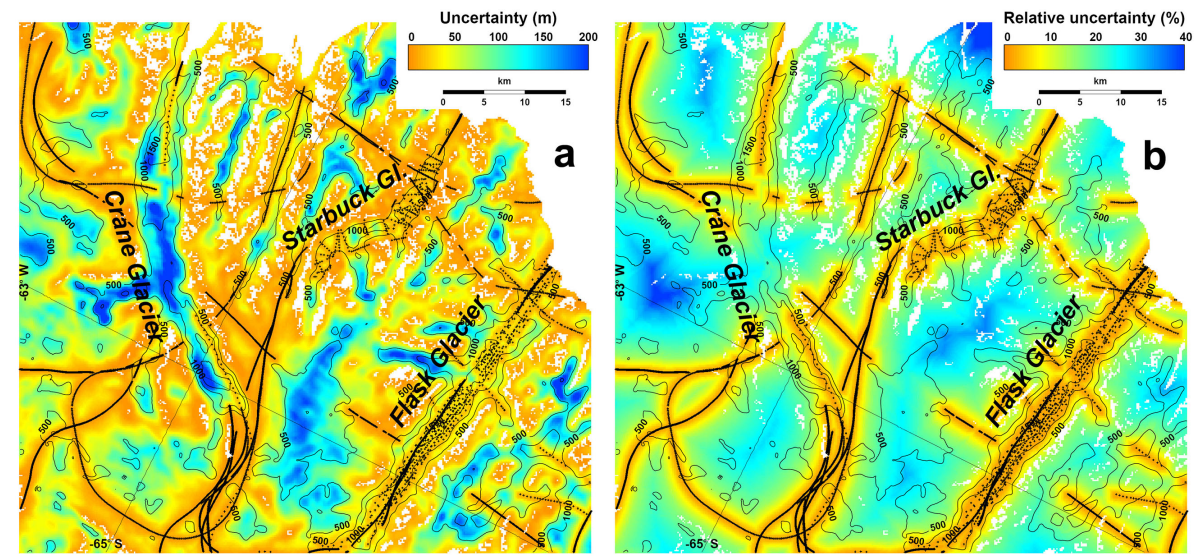

Figure 7. (a) Absolute, and (b) relative ice thickness uncertainty maps for a region around Crane/Starbuck/Flask Glacier (Fig. 1). OIB flight lines are indicated. Contours (500 $\mathrm{m}$ interval) refer to ice thickness.
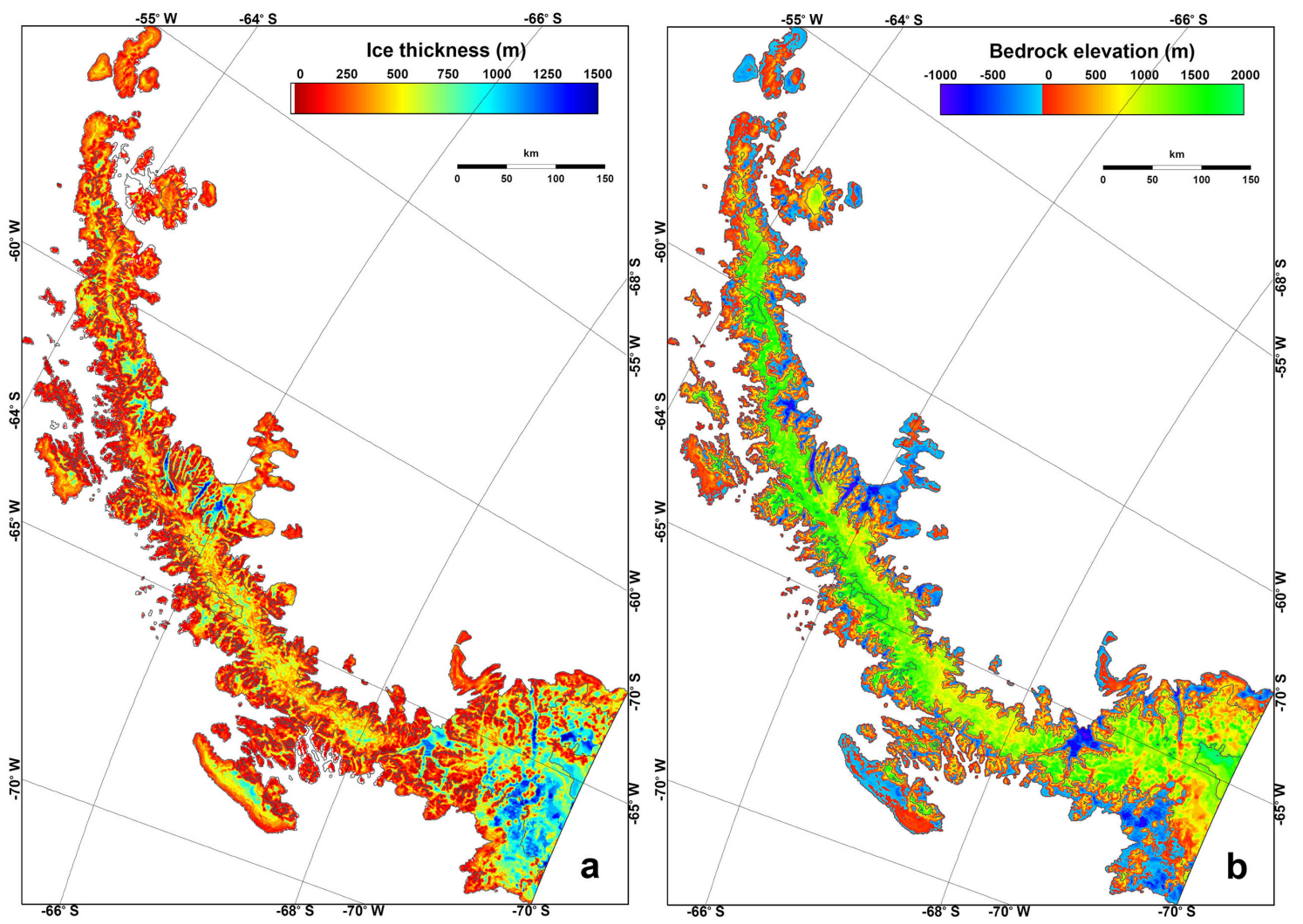

Figure 8. Inferred (a) ice thickness distribution and (b) bedrock elevation of the Antarctic Peninsula. 

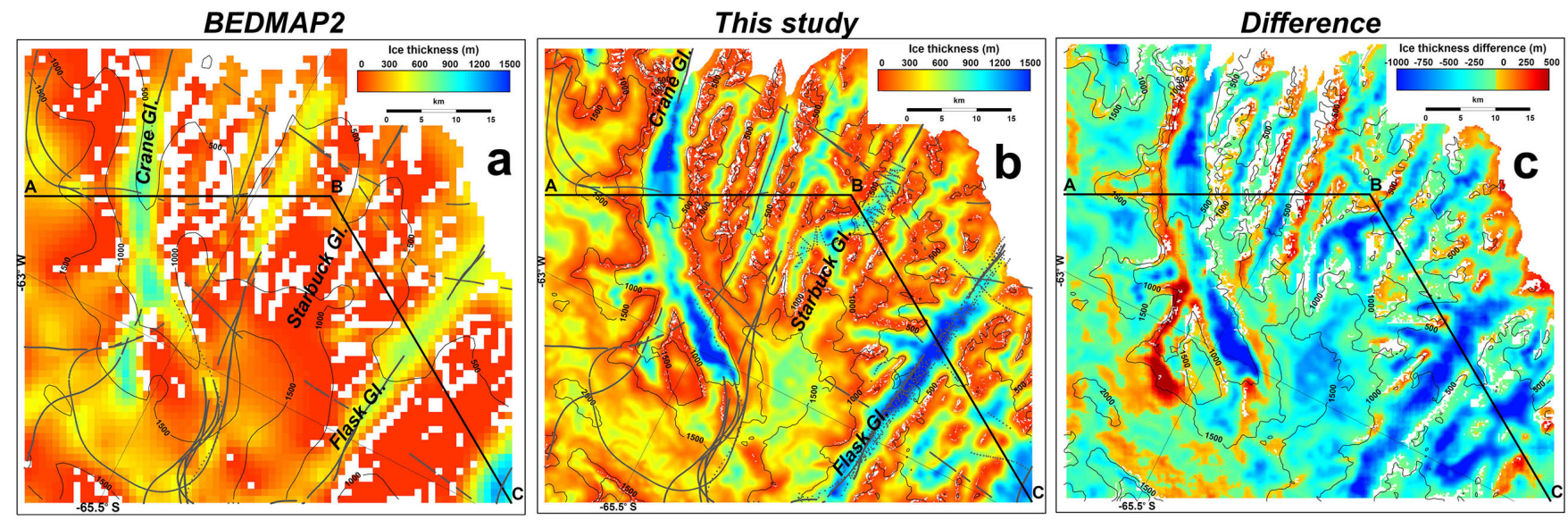

Figure 9. Comparison of Bedmap2 (Fretwell et al., 2013) to the new bedrock data set around Crane/Starbuck/Flask Glacier (Fig. 1). Ice thickness according to (a) Bedmap2, (b) this study, and (c) the difference (a-b). A profile along A-B-C is shown in Fig. 10.

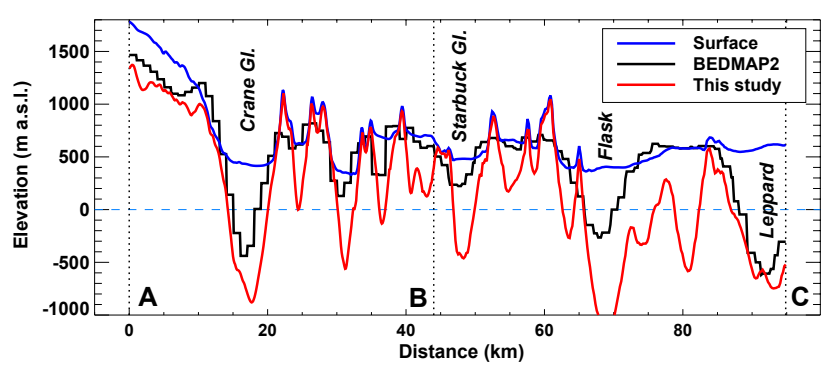

Figure 10. Comparison of bedrock elevation according to Bedmap2 and this study along the profile A-B-C (see Fig. 9).

A detailed comparison of Bedmap2 with the new data set in a region characterized by several large outlet glaciers demonstrates the considerable differences at the local scale (Fig. 9). Bedmap2 correctly indicates the location of the biggest subglacial valleys as they are relatively wide (3$5 \mathrm{~km}$ ) and covered by at least some OIB data (Fig. 9a). However, their maximum depth is often strongly underestimated, and smaller troughs, such as Starbuck Glacier with observed thicknesses of up to $1000 \mathrm{~m}$ (Farinotti et al., 2014), are almost completely missing (Figs. $9 \mathrm{~b}$ and 10). Furthermore, the new bedrock map indicates systematically higher ice thickness in the interior of the Peninsula. Local differences between the data sets can reach $1000 \mathrm{~m}$ and show a high spatial variability (Figs. $9 \mathrm{c}$ and 10 ).

A number of factors that were not included in the uncertainty assessment (Sect. 4) as their effect on calculated ice thickness is difficult to quantify, hamper the reliability of our high-resolution bedrock map to a certain degree. The model parameters are assumed to be constant over the entire study region, i.e. to not show any spatial variability depending on geographic location or local climate. This is, of course, an important simplification. For example, ice temperatures, and thus the flow rate factor $A_{\mathrm{f}}$, are likely to show variations along the glacier and to be different for the maritime northern tip of the Peninsula compared to the more continental south of the study region. Also, $f_{\mathrm{RACMO}}$ is assumed to be the same for every glacier although the bias in the downscaled RACMO data set is poorly constrained in the spatial domain. The apparent mass balance $\widetilde{b}$ (Eq. 1 ) is determined by the glacier's current dynamic imbalance. $\partial h / \partial t$ shows a high spatio-temporal variability over the Antarctic Peninsula (e.g. Berthier et al., 2012) and was only crudely approximated. As the unambiguous calibration of the model was only possible with reducing the degrees of freedom, the above effects were not taken into account. The regionally constrained calibration experiments however indicate that these simplifications have rather small effects on the final result.

The chosen approach strongly relies on the ice surface topography and its uncertainties, particularly regarding surface slope. According to Cook et al. (2012) the ASTERbased $100 \mathrm{~m}$ resolution DEM has an uncertainty of $\pm 25 \mathrm{~m}$. Sensitivity tests for individual glaciers showed that perturbing the DEM with the stated uncertainty has a relatively small effect on calculated total ice volume (less than $3 \%$ depending on the chosen glacier). Simplifications of the threedimensional geometry to the 2-D shape used for calculating semi-distributed ice thicknesses (see Fig. 2b) have the potential to introduce additional uncertainties in particular regarding branched glacier systems. However, quantifying the effect of this factor inherent to our approach was not possible.

The inferred ice thicknesses and bedrock elevations strongly depend on uncertainties in OIB data. In fact, we make the rather strong assumption that all thickness measurements are accurate, i.e. that the bedrock reflector has been correctly detected and that the uncertainties in converting travel times of the electromagnetic waves into thicknesses are small. Direct comparison of OIB thickness with groundbased GPR on Starbuck Glacier indicates good agreement of 
the two independent measurement approaches. Median and maximal deviations are contained within $3.7 \%$ and $11.7 \%$ of the local ice thickness, corresponding to $27 \mathrm{~m}$ and $45 \mathrm{~m}$, respectively, indicating that OIB also captures the bottom of deep glacial troughs (Farinotti et al., 2014). In the case of an unfavourable alignment of the profiles (e.g. along narrow subglacial valleys), a systematic underestimation due to reflections from valley side-walls however seems possible. Given the large number of measurements used we assume that random errors cancel out each other and only affect our bedrock map locally.

As the calculated ice thickness locally disagrees with direct observations based on OIB (Fig. 5) we apply a correction grid to tie our final bedrock map to the measurements (Fig. 6b). Although this procedure might locally violate mass conservation according to our simple modelling approach, we argue that forcing the final solution to fit all direct measurements is more suitable than forcing the solution to obey mass conservation calculated through one particular model. Potential future improvements of the bedrock estimate for the Antarctic Peninsula might be directed towards more strictly enforcing mass conservation and including spatially distributed surface velocity data as an immediate constraint into the ice thickness determination (see e.g. McNabb et al., 2012; Morlighem et al., 2014).

\section{Conclusions}

In this study, we further developed and applied a method to infer the complete bedrock topography of the Antarctic Peninsula north of $70^{\circ} \mathrm{S}$ with a resolution of $100 \mathrm{~m} \times$ $100 \mathrm{~m}$. Our approach allows including all available information provided by various spatially distributed data sets in order to compute thickness distribution of each individual glacier of the Peninsula. Using downscaled RACMO surface mass balances we determined mass fluxes along each glacier and inverted them using the flow law for ice and assumptions on basal sliding to obtain local ice thickness. 500000 point thickness measurements from Operation IceBridge were used to calibrate, validate and locally adjust the modelled thickness distribution. Furthermore, we used gridded ice surface velocities for the entire study region to constrain our result. The combination of these observational data with considerations of ice flow dynamics allows us to extrapolate to unmeasured catchments based on physical relations. This is a significant advantage compared to direct extrapolation approaches and makes it possible to increase spatial resolution by one order of magnitude.

Our new data set depicts the subglacial topography with great detail. Deeply incised valleys are captured and the rugged topography can be resolved. One third of the total volume is grounded below sea level reinforcing the high vulnerability of the region to changes in the system such as the break-up of ice shelves. According to our results, the Antarc- tic Peninsula has the potential of raising global sea level by $69 \pm 5 \mathrm{~mm}$. In comparison to Bedmap2 we find significantly higher mean ice thicknesses $(+48 \%)$. This systematic difference is attributed to the higher resolution of our new data set better rendering the shape of glacial troughs, and to the approach used to calculate thickness in regions not covered with direct measurements.

The bedrock data set derived in the present study might be useful for calculating the future response of glaciers of the Antarctic Peninsula using ice dynamic models and, hence, to better understand the processes triggering their rapid changes. This may offer new possibilities for studying cryospheric glacier contribution to sea-level rise.

\section{The Supplement related to this article is available online at doi:10.5194/tc-8-1261-2014-supplement.}

Acknowledgements. We thank A. Cook for the high-resolution DEM and the glacier catchments. Operation IceBridge is acknowledged for their many thickness measurements being one of the backbones of this study. RACMO surface mass balance data were provided by J. Lenaerts, P. Kuipers-Munneke and M. R. van den Broeke. Firn density estimates were produced by S. R. M. Ligtenberg, and surface velocity data by E. Rignot. H. F. J. Corr, G. H. Gudmundsson and E. C. King from the British Antarctic Survey made unpublished ice thickness data for Flask Glacier available to us. Digital glacier outcrops and ice shelf margins were retrieved from the SCAR Antarctic Digital Database. M. Funk provided helpful comments on an earlier version of the manuscript. Constructive reviews by M. Morlighem and an anonymous reviewer contributed to the final version of the paper.

Edited by: E. Larour

\section{References}

Allen, C.: IceBridge MCoRDS L2 Ice Thickness, National Snow and Ice Data Center, Boulder, Colorado, available at: http://nsidc. org/data/irmcr2.html (last access: 12 February 2014), 2013.

Bamber, J. L., Griggs, J. A., Hurkmans, R. T. W. L., Dowdeswell, J. A., Gogineni, S. P., Howat, I., Mouginot, J., Paden, J., Palmer, S., Rignot, E., and Steinhage, D.: A new bed elevation dataset for Greenland, The Cryosphere, 7, 499-510, doi:10.5194/tc-7-499-2013, 2013.

Barrand, N. E., Vaughan, D. G., Steiner, N., Tedesco, M., Kuipers Munneke, P., Broeke, M. R., and Hosking, J. S.: Trends in Antarctic Peninsula surface melting conditions from observations and regional climate modeling, J. Geophys. Res.-Earth, 118, 315-330, doi:10.1029/2012JF002559, 2013b.

Barrand, N. E., Hindmarsh, R. C. A., Arthern, R. J., Williams, C. R., Mouginot, J., Scheuchl, B., Rignot, E., Ligtenberg, S. R. M., van den Broeke, M. R., Edwards, T. L., Cook, A. J., and Simonsen, S. B.: Computing the volume response of the Antarctic Peninsula ice sheet to warming scenarios to 2200, J. Glaciol., 59, 397-409, doi:10.3189/2013JoG12J139, 2013a. 
Berthier, E., Scambos, T. A., and Shuman, C. A.: Mass loss of Larsen B tributary glaciers (Antarctic Peninsula) unabated since 2002, Geophys. Res. Lett., 39, L13501, doi:10.1029/2012GL051755, 2012.

Budd, W. F., and Allison, I.: An empirical scheme for estimating the dynamics of unmeasured glaciers, Snow and Ice (Proceedings of the Moscow Symposium, August 1971), 246-256, IAHS Publ. no. 104., 1975.

Clarke, G. K. C., Anslow, F. S., Jarosch, A. H., Radic, V., Menounos, B., Bolch, T., and Berthier, E.: Ice volume and subglacial topography for western Canadian glaciers from mass balance fields, thinning rates, and a bed stress model, J. Climate, 26, 4282-4303, doi:10.1175/JCLI-D-12-00513.1, 2013.

Cook, A. J., Vaughan, D. G., Luckman, A., and Murray, T.: A new Antarctic Peninsula glacier basin inventory and observed area changes since the 1940s, Antarct. Sci., doi:10.1017/S0954102014000200, 2014.

Cook, A. J., Fox, A. J., Vaughan, D. G., and Ferrigno, J. G.: Retreating glacier fronts on the Antarctic Peninsula over the past halfcentury, Science, 308, 541-544, doi:10.1126/science.1104235, 2005.

Cook, A. J., Murray, T., Luckman, A., Vaughan, D. G., and Barrand, N. E.: A new 100-m Digital Elevation Model of the Antarctic Peninsula derived from ASTER Global DEM: methods and accuracy assessment, Earth Syst. Sci. Data, 4, 129-142, doi:10.5194/essd-4-129-2012, 2012.

Cuffey, K. M. and Paterson, W. S. B.: The Physics of Glaciers, 4th edn., Butterworth-Heinemann, Oxford, 704 pp., 2010.

Depoorter, M., Bamber, J., Griggs, J., Lenaerts, J., Ligtenberg, S., van den Broeke, M., and Moholdt, G.: Calving fluxes and basal melt rates of Antarctic ice shelves, Nature, 502, 89-92, 2013.

Farinotti, D., Huss, M., Bauder, A., Funk, M., and Truffer, M.: A method for estimating the ice volume and ice thickness distribution of alpine glaciers, J. Glaciol., 55, 422-430, 2009.

Farinotti, D., Corr, H., and Gudmundsson, G. H.: The ice thickness distribution of Flask Glacier, Antarctic Peninsula, determined by combining radio-echo soundings, surface velocity data and flow modelling, Ann. Glaciol., 54, 18-24, doi:10.3189/2013AoG63A603, 2013.

Farinotti, D., King, E. C., Albrecht, A., Huss, M., and Gudmundsson, G. H.: The bedrock topography of Starbuck Glacier, Antarctic Peninsula, as measured by ground based radio-echo soundings, Ann. Glaciol., 55, 22-28, 2014.

Fretwell, P., Pritchard, H. D., Vaughan, D. G., Bamber, J. L., Barrand, N. E., Bell, R., Bianchi, C., Bingham, R. G., Blankenship, D. D., Casassa, G., Catania, G., Callens, D., Conway, H., Cook, A. J., Corr, H. F. J., Damaske, D., Damm, V., Ferraccioli, F., Forsberg, R., Fujita, S., Gim, Y., Gogineni, P., Griggs, J. A., Hindmarsh, R. C. A., Holmlund, P., Holt, J. W., Jacobel, R. W., Jenkins, A., Jokat, W., Jordan, T., King, E. C., Kohler, J., Krabill, W., Riger-Kusk, M., Langley, K. A., Leitchenkov, G., Leuschen, C., Luyendyk, B. P., Matsuoka, K., Mouginot, J., Nitsche, F. O., Nogi, Y., Nost, O. A., Popov, S. V., Rignot, E., Rippin, D. M., Rivera, A., Roberts, J., Ross, N., Siegert, M. J., Smith, A. M., Steinhage, D., Studinger, M., Sun, B., Tinto, B. K., Welch, B. C., Wilson, D., Young, D. A., Xiangbin, C., and Zirizzotti, A.: Bedmap2: improved ice bed, surface and thickness datasets for Antarctica, The Cryosphere, 7, 375-393, doi:10.5194/tc-7-375-2013, 2013.
Glasser, N. F., Scambos, T. A., Bohlander, J., Truffer, M., Pettit, E., and Davies, B. J.: From ice-shelf tributary to tidewater glacier: continued rapid recession, acceleration and thinning of Röhss Glacier following the 1995 collapse of the Prince Gustav Ice Shelf, Antarctic Peninsula, J. Glaciol., 57, 397-406, 2011.

Glen, J. W.: The creep of polycrystalline ice, Proc. R. Soc. Lnd., 228, 519-538, 1955.

Gogineni, S., Tammana, D., Braaten, D., Leuschen, C., Akins, T., Legarsky, J., Kanagaratnam, P., Stiles, J., Allen, C., and Jezek, K.: Coherent radar ice thickness measurements over the Greenland ice sheet, J. Geophys. Res.-Atmos., 106, 3376133772, doi:10.1029/2001JD900183, 2001.

Hock, R., de Woul, M., Radic, V., and Dyurgerov, M.: Mountain glaciers and ice caps around Antarctica make a large sea-level rise contribution, Geophys. Res. Lett., 36, L07501, doi:10.1029/2008GL037020, 2009.

Huss, M. and Farinotti, D.: Distributed ice thickness and volume of all glaciers around the globe, J. Geophys. Res.-Earth, 117, F04010, doi:10.1029/2012JF002523, 2012.

Jenkins, A. and Holland, D.: Melting of floating ice and sea level rise, Geophys. Res. Lett., 34, L16609, doi:10.1029/2007GL030784, 2007.

Joughin, I., Tulaczyk, S., Bamber, J. L., Blankenship, D., Holt, J. W., Scambos, T., and Vaughan, D. G.: Basal conditions for Pine Island and Thwaites Glaciers, West Antarctica, determined using satellite and airborne data, J. Glaciol., 55, 245-257, 2009.

Kamb, B.: Basal zone of the West Antarctic ice streams and its role in lubrication of their rapid motion, in: The West Antarctic Ice Sheet: Behavior and Environment, American Geophysical Union, Washington, D.C., 157-199, 2001.

Kamb, B. and Echelmeyer, K. A.: Stress-gradient coupling in glacier flow: I. Longitudinal averaging of the influence of ice thickness and surface slope, J. Glaciol., 32, 267-284, 1986.

Kunz, M., King, M. A., Mills, J. P., Miller, P. E., Fox, A. J., Vaughan, D. G., and Marsh, S. H.: Multi-decadal glacier surface lowering in the Antarctic Peninsula, Geophys. Res. Lett., 39, L19502, doi:10.1029/2012GL052823, 2012.

Le Brocq, A. M., Payne, A. J., and Vieli, A.: An improved Antarctic dataset for high resolution numerical ice sheet models (ALBMAP v1), Earth Syst. Sci. Data, 2, 247-260, doi:10.5194/essd-2-247-2010, 2010.

Lenaerts, J. T. M., van den Broeke, M. R., van de Berg, W. J., van Meijgaard, E., and Kuipers Munneke, P.: A new, high-resolution surface mass balance map of Antarctica (1979-2010) based on regional atmospheric climate modeling, Geophys. Res. Lett., 39, L4501, doi:10.1029/2011GL050713, 2012.

Ligtenberg, S. R. M., Helsen, M. M., and van den Broeke, M. R.: An improved semi-empirical model for the densification of Antarctic firn, The Cryosphere, 5, 809-819, doi:10.5194/tc-5-809-2011, 2011.

Ligtenberg, S. R. M.: The present and future state of the Antarctic firn layer, Ph.D. thesis, Utrecht University, ISBN 978-90-8891834-6, 2014.

Lythe, M. B. and Vaughan, D. G.: BEDMAP: a new ice thickness and subglacial topographic model of Antarctica, J. Geophys. Res.-Earth, 106, 11335-11351, doi:10.1029/2000JB900449, 2001. 
McNabb, R. W., Hock, R., O’Neel, S., Rasmussen, L. A., Ahn, Y., Braun, M., Conway, H., Herreid, S., Joughin, I., Pfeffer, W. T., Smith, B. E., and Truffer, M.: Using surface velocities to calculate ice thickness and bed topography: a case study at Columbia Glacier, Alaska, USA, J. Glaciol., 58, 1151-1164, 2012.

Meredith, M. P. and King, J. C.: Rapid climate change in the ocean west of the Antarctic Peninsula during the second half of the 20th century, Geophys. Res. Lett., 32, L19604, doi:10.1029/2005GL024042, 2005.

Morlighem, M., Rignot, E., Seroussi, H., Larour, E., Dhia, H. B., and Aubry, D.: A mass conservation approach for mapping glacier ice thickness, Geophys. Res. Lett., 38, L19503, doi:10.1029/2011GL048659, 2011.

Morlighem, M., Rignot, E., Mouginot, J., Wu, X., Seroussi, H., Larour, E., and Paden, J.: High-resolution bed topography mapping of Russell Glacier, Greenland, inferred from Operation IceBridge data, J. Glaciol., 59, 1015-1023, 2013a.

Morlighem, M., Seroussi, H., Larour, E., and Rignot, E.: Inversion of basal friction in Antarctica using exact and incomplete adjoints of a higher-order model, J. Geophys. Res.-Earth, 118, 1746-1753, doi:10.1002/jgrf.20125, 2013b.

Morlighem, M., Rignot, E., Mouginot, J., Seroussi, H., and Larour, E.: High-resolution ice-thickness mapping in South Greenland, Ann. Glaciol., 55, 64-70, 2014.

Nye, J. F.: The flow of a glacier in a channel of rectangular, elliptic or parabolic cross-section, J. Glaciol., 5, 661-690, 1965.

Oerlemans, J.: Climate Sensitivity of Franz-Josef Glacier, New Zealand, as revealed by numerical modelling, Arct. Alp. Res., 29, 233-239, 1997.

Pritchard, H. D. and Vaughan, D. G.: Widespread acceleration of tidewater glaciers on the Antarctic Peninsula, J. Geophys. Res.Earth, 112, F03S29, doi:10.1029/2006JF000597, 2007.

Pritchard, H. D., Arthern, R. J., Vaughan, D. G., and Edwards, L. A.: Extensive dynamic thinning on the margins of the Greenland and Antarctic ice sheets, Nature, 461, 971-975, doi:10.1038/nature08471, 2009.

Pritchard, H. D., Ligtenberg, S. R. M., Fricker, H. A., Vaughan, D. G., van den Broeke, M. R., and Padman, L.: Antarctic ice-sheet loss driven by basal melting of ice shelves, Nature, 484, 502-505, doi:10.1038/nature10968, 2012.

Rignot, E., Casassa, G., Gogineni, P., Krabill, W., Rivera, A., and Thomas, R.: Accelerated ice discharge from the Antarctic Peninsula following the collapse of Larsen B ice shelf, Geophys. Res. Lett., 31, L18401, doi:10.1029/2004GL020697, 2004.

Rignot, E., Mouginot, J., and Scheuchl, B.: Ice flow of the Antarctic Ice Sheet, Science, 333, 1427-1430, doi:10.1126/science.1208336, 2011.
Roberts, J. L., Warner, R. C., Young, D., Wright, A., van Ommen, T. D., Blankenship, D. D., Siegert, M., Young, N. W., Tabacco, I. E., Forieri, A., Passerini, A., Zirizzotti, A., and Frezzotti, M.: Refined broad-scale sub-glacial morphology of Aurora Subglacial Basin, East Antarctica derived by an icedynamics-based interpolation scheme, The Cryosphere, 5, 551560, doi:10.5194/tc-5-551-2011, 2011.

Rott, H., Müller, F., Nagler, T., and Floricioiu, D.: The imbalance of glaciers after disintegration of Larsen-B ice shelf, Antarctic Peninsula, The Cryosphere, 5, 125-134, doi:10.5194/tc-5-1252011, 2011.

Scambos, T. A., Bohlander, J. A., Shuman, C. A., and Skvarca, P.: Glacier acceleration and thinning after ice shelf collapse in the Larsen B embayment, Antarctica, Geophys. Res. Lett., 31, L18402, doi:10.1029/2004GL020670, 2004.

Sellier, M., Gessese, A., and Heining, C.: Analytical and numerical bedrock reconstruction in glacier flows from free surface elevation data, Proceedings of the 23rd International Congress of Theoretical and Applied Mechanics (ICTAM2012), Beijing, China, 2012.

Shi, L., Allen, C., Ledford, J., Rodriguez-Morales, F., Blake, W., Panzer, B., Prokopiack, S., Leuschen, C., and Gogineni, S.: Multichannel coherent radar depth sounder for NASA Operation Ice Bridge, in: Proceedings of the 30th IEEE International Geoscience and Remote Sensing Symposium (IGARSS 2010), Honolulu, Hawaii, USA, 1729-1732, IEEE, 2010.

Turner, J., Lachlan-Cope, T. A., Marshall, G. J., Morris, E. M., Mulvaney, R., and Winter, W.: Spatial variability of Antarctic Peninsula net surface mass balance, J. Geophys. Res.-Atmos., 107, 4173, doi:10.1029/2001JD000755, 2002.

van Pelt, W. J. J., Oerlemans, J., Reijmer, C. H., Pettersson, R., Pohjola, V. A., Isaksson, E., and Divine, D.: An iterative inverse method to estimate basal topography and initialize ice flow models, The Cryosphere, 7, 987-1006, doi:10.5194/tc-7-987-2013, 2013.

Vaughan, D. G., Marshall, G. J., Connolley, W. M., Parkinson, C., Mulvaney, R., Hodgson, D. A., King, J. C., Pudsey, C. J., and Turner, J.: Recent rapid regional climate warming on the Antarctic Peninsula, Clim. Change, 60, 243-274, 2003.

Zagorodnov, V., Nagornov, O., Scambos, T. A., Muto, A., MosleyThompson, E., Pettit, E. C., and Tyuflin, S.: Borehole temperatures reveal details of 20th century warming at Bruce Plateau, Antarctic Peninsula, The Cryosphere, 6, 675-686, doi:10.5194/tc-6-675-2012, 2012. 